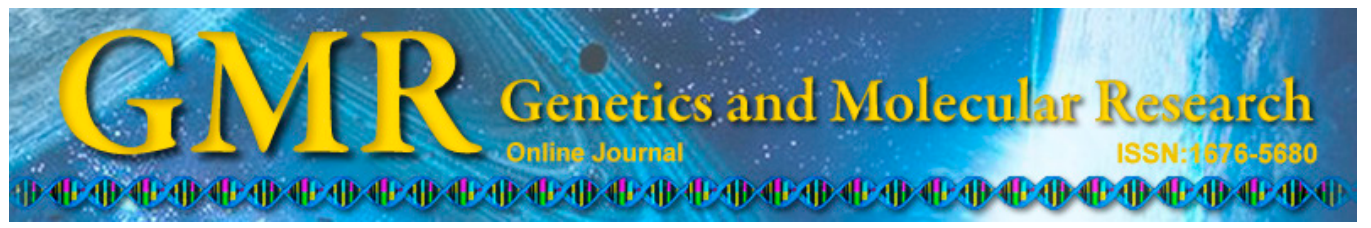

\title{
Optimum conditions for inducing laccase production in Lentinus crinitus
}

\author{
J.S. Valle ${ }^{1,2}$, L.P.S. Vandenberghe ${ }^{2}$, T.T. Santana ${ }^{1}$, P.H. Almeida ${ }^{1}$, \\ A.M. Pereira' ${ }^{1}$ G.A. Linde ${ }^{1}$, N.B. Colauto ${ }^{1}$ and C.R. Soccol ${ }^{2}$ \\ ${ }^{1}$ Laboratório de Biologia Molecular, \\ Pós-Graduação em Biotecnologia Aplicada à Agricultura, \\ Universidade Paranaense, Umuarama, PR, Brasil \\ ${ }^{2}$ Laboratório de Processos Biotecnológicos, \\ Departamento de Engenharia Química, Universidade Federal do Paraná, \\ Curitiba, PR, Brasil
}

Corresponding author: J.S. Valle

E-mail: jsvalle@unipar.br

Genet. Mol. Res. 13 (4): 8544-8551 (2014)

Received February 29, 2014

Accepted May 29, 2014

Published October 20, 2014

DOI http://dx.doi.org/10.4238/2014.October.20.31

\begin{abstract}
Laccases are environmentally friendly alternatives in many important applications such as in bioremediation, biopulping, textile, and the food industry. They have wide substrate specificity, can oxidize a broad range of compounds, and show potential for use in various industrial processes. Therefore, developing methods to increase laccase production is important. In the current study, we aimed to identify optimum conditions for inducing laccase production in the basidiomycete Lentinus crinitus cultivated under varying nitrogen concentrations and in the presence of potential inducers of laccase production, including copper and phenolic compounds. Peak enzymatic activity $(11,977 \mathrm{U} / \mathrm{L})$ occurred at higher nitrogen concentrations (2.8 $\mathrm{g} / \mathrm{L}$ nitrogen). Regardless of the nitrogen concentration, addition of copper increased the laccase activity and decreased mycelial growth, with maximum laccase activity $(14,320 \mathrm{U} / \mathrm{L})$ observed at the highest nitrogen concentration combined with $150 \mu \mathrm{M} \mathrm{CuSO}$. In addition,
\end{abstract}


ethanol $(0.5$ or $1.0 \mathrm{mM})$ and guaiacol $(1.5 \mathrm{mM})$ increased laccase production to $15,000,14,800$, and $14,850 \mathrm{U} / \mathrm{L}$, respectively. Our findings highlighted the optimum conditions for producing $L$. crinitus derived laccase as potential alternatives to the conventional production and application of the enzyme.

Key words: Aromatic compounds; Copper; Laccase; Nitrogen; Lentinus crinitus

\section{INTRODUCTION}

In nature, lignin degradation occurs through the action of extracellular enzymes such as lignin peroxidases, manganese peroxidases, and laccases. Laccases ( $p$-diphenol:oxygen oxidoreductase, EC 1.10.3.2) use the copper ion redox capacity to catalyze the oxidation of a large variety of phenolic substrates, reducing oxygen to water (Piscitelli et al., 2011). Because laccases can considerably reduce phenolic compounds, they are environmentally friendly and can be used as alternatives in several applications such as textile dye and cellulose bleaching, bioremediation, detoxification, and waste and effluent treatment (Strong and Claus, 2011).

Lentinus crinitus (L.) Fr. is a fungus (Basidiomycota) that may produce laccase (Niebisch et al., 2010). Despite its potential and the necessity to evaluate alternative microorganisms with high yields of enzyme production, no previous studies describe the cultivation conditions that affect the laccase production of $L$. crinitus.

It has been shown that the source and concentration of nitrogen in cultivation media affect laccase production (Piscitelli et al., 2011). An important nitrogen source for enzyme production in basidiomycetes is urea. Previous studies have evaluated both protein and nonprotein sources of nitrogen, and urea was shown to be one of the best sources for laccase production by Pleurotus ostreatus (Hou et al., 2004) and Trametes versicolor (Mikiashvili et al., 2005). However, changes in laccase activity related to the nitrogen levels constitute a debatable issue; some studies have reported increased activity under non-limiting nitrogen conditions, while others reported opposite results (Giardina et al., 2010). Another important variable for laccase production is the presence of inducers. For basidiomycetes, different laccase inducers have been identified, including 2,6-dimethoxyphenol and pyrogallol for Cerrena unicolor (Elisashvili et al., 2010) and guaiacol and 3,5-dihydroxytoluene for Trametes sp (Xiao et al., 2004). The use of laccase inducers such as copper and phenolic compounds shows distinct effects depending on the fungus species or strain (Piscitelli et al., 2011). Therefore, in order to induce optimal enzyme secretion, fungus-specific inducers must be identified.

L. crinitus has the potential to produce laccase, but currently, there is a lack of information regarding the effect of cultivation media on laccase production. For these reasons, we aimed to evaluate the effects of nitrogen concentration and laccase inducers on L. crinitus enzyme production in submerged cultivation.

\section{MATERIAL AND METHODS}

\section{Microorganism and cultivation conditions}

L. crinitus strain U9-1, from the culture collection of Laboratório de Biologia Molecular of Universidade Paranaense, Brazil, was isolated in 2009 and preserved according to meth- 
ods described by Mantovani et al. (2012). The strain was cultivated in an Erlenmeyer flask $\left(250 \mathrm{~mL}\right.$ ) containing $60 \mathrm{~mL}$ liquid medium consisting of $1.5 \mathrm{~g} / \mathrm{L} \mathrm{KH}_{2} \mathrm{PO}_{4}, 0.5 \mathrm{~g} / \mathrm{L} \mathrm{MgSO}_{4}, 0.5$ $\mathrm{g} / \mathrm{L} \mathrm{KCl}, 0.036 \mathrm{~g} / \mathrm{L} \mathrm{FeSO}_{4} \cdot \mathrm{H}_{2} \mathrm{O}, 0.035 \mathrm{~g} / \mathrm{L} \mathrm{ZnSO}{ }_{4} \cdot \mathrm{H}_{2} \mathrm{O}$, and $10 \mathrm{~g} / \mathrm{L}$ glucose. After autoclaving at $121^{\circ} \mathrm{C}$ for $20 \mathrm{~min}, 300 \mathrm{~g} / \mathrm{L}$ urea that had been filtered with a $0.22-\mu \mathrm{m}$ pore filter (Millipore; Billerica, MA, USA) was added to a final concentration of $0.28 \mathrm{~g} / \mathrm{L}$ or $2.8 \mathrm{~g} / \mathrm{L}$ nitrogen in the cultivation medium. The liquid medium was inoculated with 3 discs of $2 \%$ malt extract agar medium (w/v) containing mycelia and incubated at $28^{\circ} \mathrm{C}$ in the dark. After 4 days of mycelial growth, $30 \mathrm{mM} \mathrm{CuSO}_{4}$ was added to obtain final concentrations of $0,50,100,150,200$, 250 , or $300 \mu \mathrm{M}$ in the cultivation medium. Laccase activity was measured every 3 days. The most favorable nitrogen and $\mathrm{CuSO}_{4}$ conditions for laccase production were used to evaluate the effect of inducers on enzymatic activity. Pyrogallol (1,2,3-trihydroxybenzene), veratryl alcohol (3,4-dimethoxybenzyl alcohol), xylidine (2,5-dimethylaniline), vanillin (4-hydroxy3-methoxybenzaldehyde), guaiacol (2-methoxyphenol), and ethanol were used. For each test, $5 \mathrm{mM}$ of each inducer was added to the cultivation medium to obtain final concentrations of $0,0.5,1.0$, or $1.5 \mathrm{mM}$.

At the end of cultivation, the mycelial biomass was centrifuged at $1699 \mathrm{~g}$ at $4^{\circ} \mathrm{C}$ for $15 \mathrm{~min}$. The precipitate was washed 3 times with $30 \mathrm{~mL}$ ultrapure water and the sample was centrifuged again under the same conditions. Total mycelial biomass was dried at $65^{\circ} \mathrm{C}$ with air circulation until a constant mass was reached.

All experiments were conducted using 4 replicates. The difference among averages was calculated using analysis of variance with the Tukey test $(\mathrm{P} \leq 0.05)$.

\section{Laccase assay}

Laccase (EC 1.10.3.2) activity was determined by oxidation of 2,2'-azino-bis3-ethylbenzothiazoline-6-sulfonic acid (ABTS; Sigma; St. Louis, MO, USA). The reaction mixture contained a sample of $200 \mu \mathrm{L}$ from the cultivation medium, $700 \mu \mathrm{L}$ water, $450 \mu \mathrm{L}$ sodium acetate buffer $(0.1 \mathrm{M} ; \mathrm{pH} 5.0)$, and $150 \mu \mathrm{L}$ ABTS $(1 \mathrm{mM})$. The mixture was incubated at $30^{\circ} \mathrm{C}$ for $10 \mathrm{~min}$ and the reaction was interrupted by the addition of $100 \mu \mathrm{L} 5 \%$ trichloroacetic acid $(\mathrm{w} / \mathrm{v})$. The volume was adjusted to $5 \mathrm{~mL}$ and absorbance was measured at $420 \mathrm{~nm}$. Oxidation of ABTS was followed by an absorbance increase at $420 \mathrm{~nm}\left(\varepsilon=36,000 \mathrm{M}^{-1} \cdot \mathrm{cm}^{-1}\right)$. A mixture of the $200-\mu \mathrm{L}$ sample, $850 \mu \mathrm{L}$ water, and $450 \mu \mathrm{L}$ sodium acetate buffer and a mixture of 900 $\mu \mathrm{L}$ water, $450 \mu \mathrm{L}$ sodium acetate buffer, and $150 \mu \mathrm{L}$ ABTS were used as analytical controls. Enzyme activities were expressed in international units (U), which is defined as the amount of enzyme that oxidizes $1 \mu \mathrm{mol}$ substrate per minute.

\section{RESULTS AND DISCUSSION}

\section{Laccase production in liquid medium containing different concentrations of nitrogen}

Laccase activity reached $3215 \mathrm{U} / \mathrm{L}$ in medium containing $0.28 \mathrm{~g} / \mathrm{L}$ nitrogen, while it was increased to $11,977 \mathrm{U} / \mathrm{L}$ at the higher nitrogen concentration of $2.8 \mathrm{~g} / \mathrm{L}$. This is an increase of $272 \%$ (Figure 1 and 2). It is important to note here that laccase activity was similar at both nitrogen concentrations until day 13 of cultivation when there was an increase $(\mathrm{P} \leq 0.05)$ in the enzymatic activity in the medium with higher nitrogen concen- 
tration. This increase was sustained until the end of the cultivation. Nitrogen affects laccase production at the transcriptional level, and the expression of different laccase genes appears to be regulated by a process mediated by nitrilase family member 2-type proteins, which are involved in regulating nitrogen metabolism (Piscitelli et al., 2011). Soden and Dobson (2001) identified consensus sequences corresponding to nitrilase family member 2 binding sites in the promoter regions of laccase genes of Pleurotus sajor-caju (likely Lentinus sajor-caju), suggesting the involvement of this type of protein in gene expression. Furthermore, nitrogen distinctly affects laccase production in the fungus (Giardina et al., 2010). For Ganoderma lucidum, D'Souza et al. (1996) evaluated the effect of nitrogen concentration (0.066-0.66 g/L nitrogen) and verified higher laccase production $(2880 \mathrm{U} / \mathrm{L})$ at higher nitrogen concentration, while Hou et al. (2004) verified higher laccase production $(85,000 \mathrm{U} / \mathrm{L})$ at lower nitrogen concentration (0.23-2.3 g/L nitrogen) in P. ostreatus. The fact that nitrogen sources and concentration ranges differ greatly in several studies on basidiomycetes' laccase activity hamper any comparison of results.

The addition of copper increased $(\mathrm{P} \leq 0.05)$ the laccase activity regardless of the nitrogen concentration in the cultivation medium (Figures 1 and 2). Increased laccase production $(14,320 \mathrm{U} / \mathrm{L})$ was observed in the medium containing higher nitrogen concentration and 150 $\mu \mathrm{M} \mathrm{CuSO}_{4}$ (Figure 2). This result represents an increase in laccase activity of $19.5 \%$ compared to activity in the absence of copper (11,970 U/L).

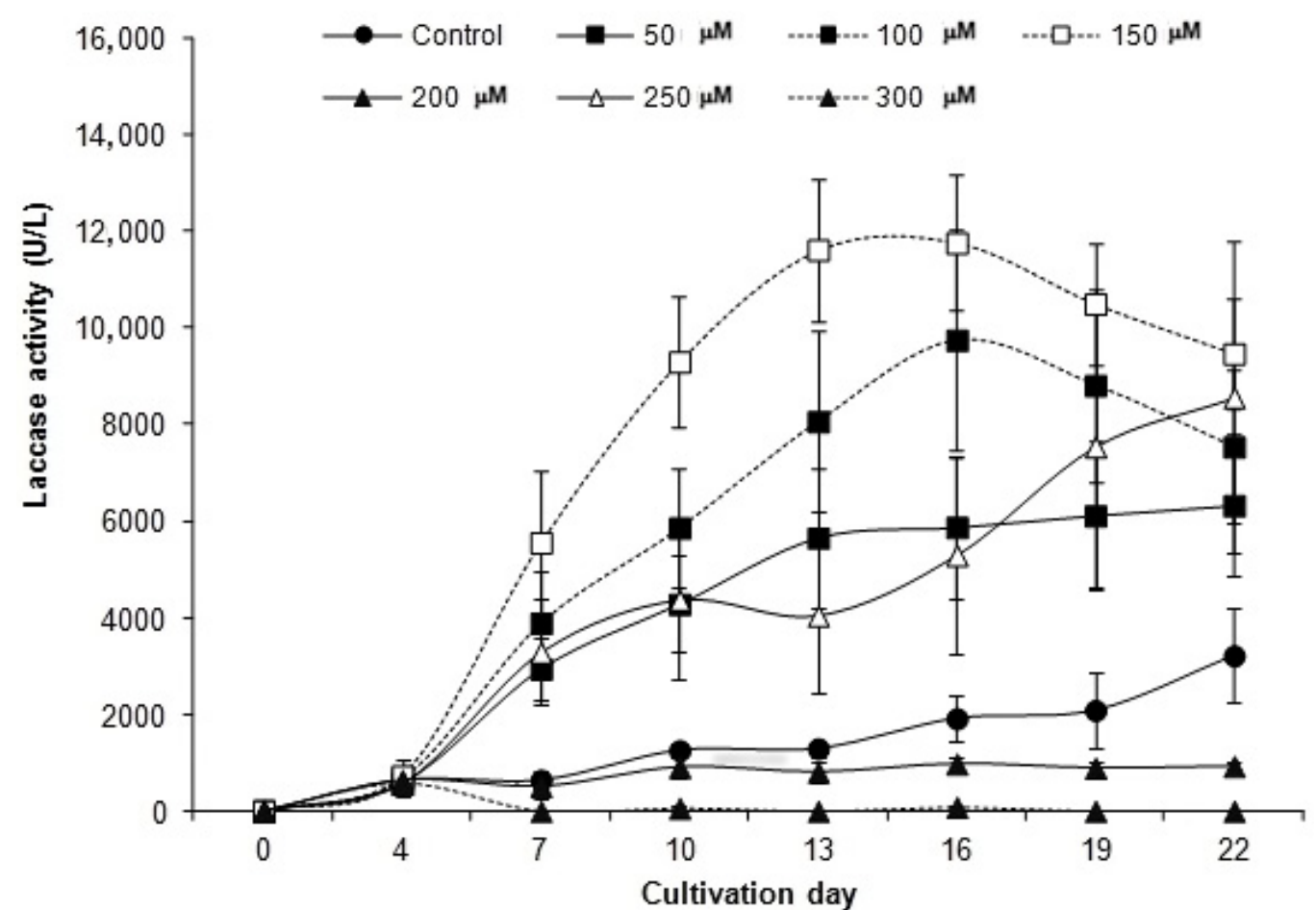

Figure 1. Laccase activity of Lentinus crinitus at 22 cultivation days with liquid medium composed of $1.5 \mathrm{~g} / \mathrm{L}$ $\mathrm{KH}_{2} \mathrm{PO}_{4}, 0.5 \mathrm{~g} / \mathrm{L} \mathrm{MgSO}_{4}, 0.5 \mathrm{~g} / \mathrm{L} \mathrm{KCl}, 0.036 \mathrm{~g} / \mathrm{L} \mathrm{FeSO} \cdot \mathrm{H}_{2} \mathrm{O}, 0.035 \mathrm{~g} / \mathrm{L} \mathrm{ZnSO}{ }_{4} \cdot \mathrm{H}_{2} \mathrm{O}$, and $10 \mathrm{~g} / \mathrm{L}$ glucose, with addition of $0.28 \mathrm{~g} / \mathrm{L}$ nitrogen (urea) and $\mathrm{CuSO}_{4}$ concentration of 0 (control), 50, 100, 150, 200, 250, or $300 \mu \mathrm{M}$. 


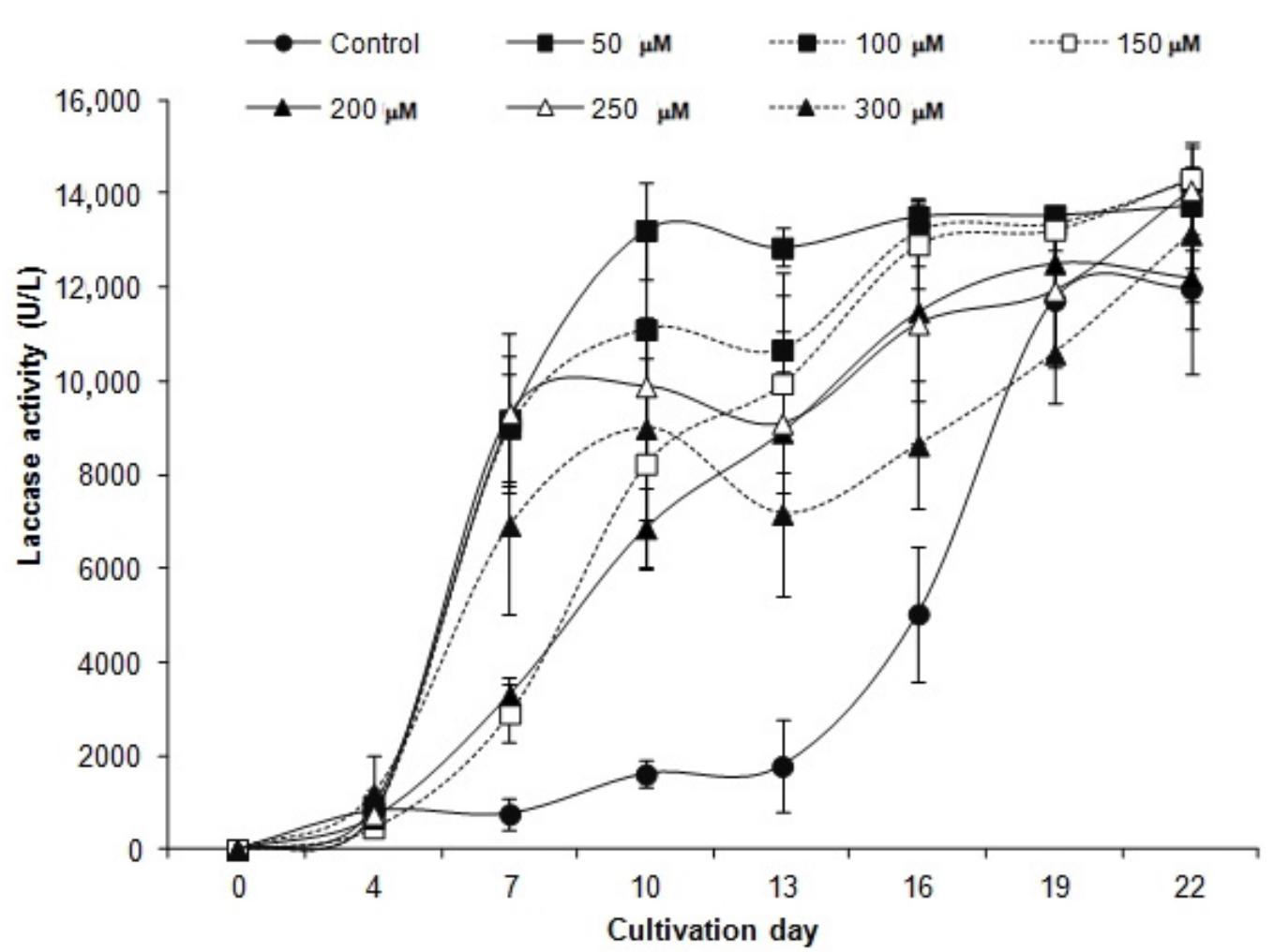

Figure 2. Laccase activity of Lentinus crinitus at 22 cultivation days with liquid medium composed of $1.5 \mathrm{~g} / \mathrm{L}$ $\mathrm{KH}_{2} \mathrm{PO}_{4}, 0.5 \mathrm{~g} / \mathrm{L} \mathrm{MgSO}, 0.5 \mathrm{~g} / \mathrm{L} \mathrm{KCl}, 0.036 \mathrm{~g} / \mathrm{L} \mathrm{FeSO} \cdot \mathrm{H}_{2} \mathrm{O}, 0.035 \mathrm{~g} / \mathrm{L} \mathrm{ZnSO} \cdot \cdot \mathrm{H}_{2} \mathrm{O}$, and $10 \mathrm{~g} / \mathrm{L}$ glucose, with addition of $2.8 \mathrm{~g} / \mathrm{L}$ nitrogen (urea) and $\mathrm{CuSO}_{4}$ concentration of 0 (control), 50, 100, 150, 200, 250, or $300 \mu \mathrm{M}$.

Copper is thought to be one of the most efficient laccase inducers. Copper regulates laccase gene expression in several fungi (Karp et al., 2012) via metal-responsive elements that are present in the laccase gene promoter region and that are indirectly affected by the presence of copper in the cultivation medium (Piscitelli et al., 2011). Studies using different concentrations of $\mathrm{CuSO}_{4}$ showed that different species respond distinctly to the addition of this metal. Fonseca et al. (2010) verified that different species of basidiomycetes (Ganoderma applanatum, Peniophora sp, Pycnoporus sanguineus, and Coriolus versicolor) produced more laccase in the presence of $500 \mu \mathrm{M}$ copper. Peniophora sp was the best laccase producer under this condition (4140 U/L), but G. applanatum was particularly sensitive to the addition of copper, increasing the production $(1850 \mathrm{U} / \mathrm{L})$ in the presence of copper. Our results agree with those of Giardina et al. (1999), who observed that $P$. ostreatus produced a significantly greater amount of laccase $(30,000 \mathrm{U} / \mathrm{L})$ in nitrogen-rich medium and in the presence of $150 \mu \mathrm{M} \mathrm{CuSO}_{4}$ compared to that produced in the absence of copper (4000 U/L). Shutova et al. (2008) used higher $\mathrm{CuSO}_{4}$ concentrations than those used in our study $(1500-2000 \mu \mathrm{M})$ and observed positive effects on laccase activity in Lentinus tigrinus $(47,000 \mathrm{U} / \mathrm{L})$. The addition of $300 \mu \mathrm{M} \mathrm{CuSO}_{4}$ inhibited laccase activity in L. crinitus grown in media containing lower nitrogen concentrations (Figure 2), but did not affect laccase activity in media containing higher nitrogen concentrations (Figure 1). Distinct responses to copper revealed the importance of evaluating this 
fungus regarding the response to a broad concentration range of copper, as small variations in $\mathrm{CuSO}_{4}$ concentration greatly altered enzyme expression and activity.

The highest nitrogen concentration decreased mycelial biomass production by $55 \%$ (Figure 3), while increased $\mathrm{CuSO}_{4}$ decreased mycelial biomass production only when combined with the lowest nitrogen concentration (Figure 3). In the medium containing $0.28 \mathrm{~g} / \mathrm{L}$ nitrogen, mycelial biomass was reduced by $35 \%$ after the addition of $50 \mu \mathrm{M} \mathrm{CuSO}_{4}$ and $88 \%$ after addition of $300 \mu \mathrm{M} \mathrm{CuSO}_{4}$ (Figure 3).

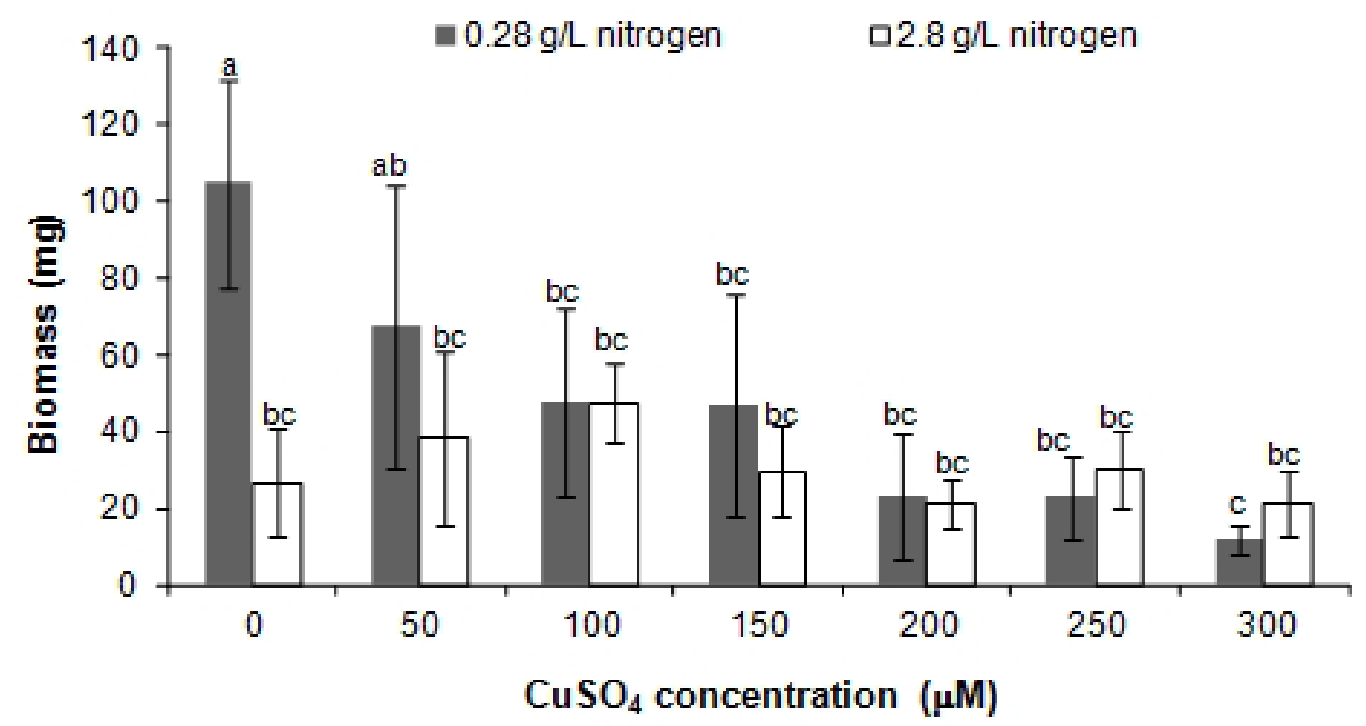

Figure 3. Mycelial biomass of Lentinus crinitus after 22 cultivation days in liquid medium composed of $0.5 \mathrm{~g} / \mathrm{L}$ $\mathrm{KH}_{2} \mathrm{PO}_{4}, 0.5 \mathrm{~g} / \mathrm{L} \mathrm{MgSO}_{4}, 0.5 \mathrm{~g} / \mathrm{L} \mathrm{KCl}, 0.036 \mathrm{~g} / \mathrm{L} \mathrm{FeSO}_{4} \cdot \mathrm{H}_{2} \mathrm{O}, 0.035 \mathrm{~g} / \mathrm{L} \mathrm{ZnSO} \cdot \mathrm{H}_{2} \mathrm{O}$, and $10 \mathrm{~g} / \mathrm{L}$ glucose, with addition of $0.28 \mathrm{~g} / \mathrm{L}$ or $2.8 \mathrm{~g} / \mathrm{L}$ nitrogen (urea) and with $\mathrm{CuSO}_{4}$ concentration of 0 (control), 50, 100, 150, 200, 250, or $300 \mu \mathrm{M}$. Averages indicated by the same letters did not differ statistically according to the results of the Tukey test $(\mathrm{P} \leq 0.05)$.

It has been suggested that copper may be toxic to fungi and may cause growth inhibition, enzyme inactivation, metabolic alterations, and production of oxygen-reactive species (Krumova et al., 2012). In this study, we observed no relationship between laccase production and mycelial biomass. The highest laccase activity $(14,320 \mathrm{U} / \mathrm{L})$ was obtained in medium containing $2.8 \mathrm{~g} / \mathrm{L}$ nitrogen and $150 \mu \mathrm{M} \mathrm{CuSO}_{4}$. However, in this medium, mycelial biomass production was $72 \%$ lower than in medium with $0.28 \mathrm{~g} / \mathrm{L}$ nitrogen and without $\mathrm{CuSO}_{4}$ addition.

\section{Selection of potential inducer compounds of laccase activity}

The conditions that promoted the highest laccase activity $(2.8 \mathrm{~g} / \mathrm{L}$ nitrogen and 150 $\mu \mathrm{M} \mathrm{CuSO}$ ) were used to evaluate other potential inducer compounds. Among the evaluated compounds, only ethanol $(0.5$ or $1.0 \mathrm{mM})$ and guaiacol $(1.5 \mathrm{mM})$ increased laccase activity $(\mathrm{P} \leq 0.05)$ (Table 1). Other compounds tested did not induce laccase activity compared to the control. 
Table 1. Laccase activity of Lentinus crinitus (means \pm standard deviation) with different compounds.

\begin{tabular}{lcccccc}
\hline $\begin{array}{l}\text { Compound concentration } \\
(\mathrm{mM})\end{array}$ & \multicolumn{5}{c}{ Laccase activity (U/L) } \\
\cline { 2 - 6 } & Veratryl alcohol & Ethanol & Guaiacol & Pyrogallol & Vanillin & Xylidine \\
\hline 0 & $14,380 \pm 250^{\mathrm{ab}}$ & $14,380 \pm 250^{\mathrm{ab}}$ & $14,380 \pm 250^{\mathrm{ab}}$ & $14,380 \pm 250^{\mathrm{ab}}$ & $14,380 \pm 250^{\mathrm{ab}}$ & $14,380 \pm 250^{\mathrm{ab}}$ \\
0.5 & $14,400 \pm 103^{\mathrm{ab}}$ & $15,000 \pm 170^{\mathrm{a}}$ & $14,600 \pm 336^{\mathrm{ab}}$ & $12,900 \pm 205^{\mathrm{bc}}$ & $14,700 \pm 260^{\mathrm{ab}}$ & $14,000 \pm 290^{\mathrm{ab}}$ \\
1.0 & $14,440 \pm 240^{\mathrm{ab}}$ & $14,800 \pm 207^{\mathrm{a}}$ & $14,300 \pm 95^{\mathrm{ab}}$ & $12,500 \pm 270^{\mathrm{c}}$ & $14,600 \pm 140^{\mathrm{ab}}$ & $14,000 \pm 340^{\mathrm{ab}}$ \\
1.5 & $14,300 \pm 590^{\mathrm{ab}}$ & $14,300 \pm 907^{\mathrm{ab}}$ & $14,850 \pm 70^{\mathrm{a}}$ & $11,050 \pm 890^{\mathrm{d}}$ & $14,300 \pm 280^{\mathrm{ab}}$ & $14,100 \pm 370^{\mathrm{ab}}$ \\
\hline
\end{tabular}

Averages indicated by the same letters did not differ statistically according to the Tukey test $(\mathrm{P} \leq 0.05)$.

An increase in laccase activity was obtained by adding phenolic and aromatic compounds to the cultivation medium. Laccase activity may be related to the development of the fungal response to toxic compounds produced during lignin degradation (Piscitelli et al., 2011). In our study, known laccase inducers of several fungi such as pyrogallol, veratryl alcohol, xylidine, and vanillin did not affect $L$. crinitus laccase activity, suggesting that laccase induction is directly dependent on the fungus species. Other reports of laccase induction in L. crinitus using these compounds were not found in the literature.

Ethanol and guaiacol have also been used as laccase inducers for other fungi. Lomascolo et al. (2003) observed that addition of $0.76 \mathrm{mM}$ ethanol increased laccase activity (266,000 U/L) by Pycnoporus cinnabarinus when compared to other inducers. However, Kocyigit et al. (2012) reported that addition of $650 \mathrm{mM}$ ethanol or $1 \mathrm{mM}$ guaiacol in the cultivation of Trametes trogii did not increase laccase activity under both conditions $(14,650 \mathrm{U} / \mathrm{L}$ and $15,980 \mathrm{U} / \mathrm{L}$, respectively). Most laccase inducers are toxic and expensive. Ethanol may induce laccase activity by $L$. crinitus and shows low toxicity, is inexpensive, and is easy to obtain; therefore, the use of inexpensive compounds such as urea, copper sulfate, and ethanol may be alternatives for the production of higher laccase activities in L. crinitus submerged cultivation.

In conclusion, the concentration of nitrogen and $\mathrm{CuSO}_{4}$ in the cultivation medium affected laccase production by L. crinitus. Only ethanol and guaiacol induced laccase activity, while pyrogallol, veratryl alcohol, xylidine, and vanillin were not effective. The maximum laccase activity occurred in the presence of $2.8 \mathrm{~g} / \mathrm{L}$ nitrogen as urea, $150 \mu \mathrm{M} \mathrm{CuSO}_{4}, 0.5 \mathrm{mM}$ ethanol, and $1.5 \mathrm{mM}$ guaiacol.

\section{ACKNOWLEDGMENTS}

The authors thank Universidade Paranaense (UNIPAR) for providing funding. J.S. Valle received financial support from UNIPAR. L.P.S. Vandenberghe wishes to thank Coordenação de Aperfeiçoamento de Pessoal de Nível Superior (CAPES) and Conselho Nacional de Desenvolvimento Científico e Tecnológico (CNPq).

\section{REFERENCES}

D'Souza TM, Boominathan K and Reddy CA (1996). Isolation of laccase gene-specific sequences from white rot and brown rot fungi by PCR. Appl. Environ. Microbiol. 62: 3739-3744.

Elisashvili V, Kachlishvili E, Khardziani T and Agathos SN (2010). Effect of aromatic compounds on the production of laccase and manganese peroxidase by white-rot basidiomycetes. J. Ind. Microbiol. Biotechnol. 37: 1091-1096.

Fonseca MI, Shimizu E, Zapata PD and Villalba LL (2010). Copper inducing effect on laccase production of white rot fungi native from Misiones (Argentina). Enzyme Microb. Technol. 46: 534-539.

Giardina P, Palmieri G, Scaloni A, Fontanella B, et al. (1999). Protein and gene structure of a blue laccase from Pleurotus 
ostreatus. Biochem. J. 341: 655-663.

Giardina P, Faraco V, Pezzella C, Piscitelli A, et al. (2010). Laccases: a never-ending story. Cell Mol. Life Sci. 67: 369385.

Hou H, Zhou J, Wang J, Du C, et al. (2004). Enhancement of laccase production by Pleurotus ostreatus and its use for the decolorization of anthraquinone dye. Process Biochem. 39: 1415-1419.

Karp SG, Faraco V, Amore A, Birolo L, et al. (2012). Characterization of laccase isoforms produced by Pleurotus ostreatus in solid state fermentation of sugarcane bagasse. Bioresour. Technol. 114: 735-739.

Kocyigit S, Pazarbasi MB, Yasa I, Ozdemir G, et al. (2012). Production of laccase from Trametes trogii TEM H2: a newly isolated white-rot fungus by air sampling. J. Basic Microb. 52: 1-9.

Krumova ET, Stoitsova SR, Paunova-Krasteva TS, Pashova SB, et al. (2012). Copper stress and filamentous fungus Humicola lutea. Can. J. Microbiol. 58: 1335-1343.

Lomascolo A, Record E, Herpoel-Gimbert I, Delattre M, et al. (2003). Overproduction of laccase by a monokaryotic strain of Pycnoporus cinnabarinus using ethanol as inducer. J. Appl. Microbiol. 94: 618-624.

Mantovani TRD, Tanaka HS, Umeo SH, Zaghi Jr LL, et al. (2012). Cryopreservation at -20 and -70 oC of Pleurotus ostreatus on grains. Indian J. Microbiol. 52: 484-482.

Mikiashvili N, Elisashvili V, Wasser S and Nevo E (2005). Carbon and nitrogen sources influence the ligninolytic enzyme activity of Trametes versicolor. Biotechnol. Lett. 27: 955-959.

Niebisch CH, Malinowski AK, Schadeck R, Mitchell DA, et al. (2010). Decolorization and biodegradation of reactive blue 220 textile dye by Lentinus crinitus extracellular extract. J. Hazard. Mater. 180: 316-322.

Piscitelli A, Giardina P, Lettera V, Pezzella C, et al. (2011). Induction and transcriptional regulation of laccases in fungi. Curr. Genomics 12: 104-112.

Shutova VV, Revin VV and Makushina I (2008). The effect of copper ions on the production of laccase by the fungus Lentinus (Panus) tigrinus. Prikl. Biokhim. Mikrobiol. 44: 683-687.

Soden DM and Dobson AD (2001). Differential regulation of laccase gene expression in Pleurotus sajor-caju. Microbiology 147: 1755-1763.

Strong PJ and Claus H (2011). Laccase: A review of its past and its future in bioremediation. Crit. Rev. Environ. Sci. Tecnol. 41: 373-434.

Xiao YZ, Chen Q, Hang J, Shi YY, et al. (2004). Selective induction, purification and characterization of a laccase isozyme from the basidiomycete Trametes sp. AH28-2. Mycologia 96: 26-35. 